\title{
Arsenic geochemistry of the sediments of the shallow aquifer and its correlation with the groundwater, Rangpur, Bangladesh
}

\author{
Sudip Saha ${ }^{1}$ A. H. M. Selim Reza ${ }^{1}$ Mrinal Kanti Roy ${ }^{1}$
}

Received: 16 April 2020 / Accepted: 8 September 2021 / Published online: 23 September 2021

(c) The Author(s) 2021

\begin{abstract}
The geochemical analysis of the shallow aquifer sediments of the area of investigation reveals that they are acidic in nature. The mean electrical conductivity of the deposits is $1.16 \mathrm{dS} / \mathrm{m}$ that indicates very low or negligible effects of salinity of the sediments of the Rangpur division. The median values of the concentrations of total organic carbon, total nitrogen and sulphur are $0.20 \%, 0.02 \%$ and $58.68 \mathrm{mg} / \mathrm{kg}$, respectively. The trend of the average heavy metal concentrations of the investigated area can be shown as $\mathrm{Fe}>\mathrm{As}>\mathrm{Cu}>\mathrm{Zn}$. The average concentrations of arsenic of the sediments of the study area are $3.52 \mathrm{mg} / \mathrm{kg}$. Sulphur is significantly, positively correlated with copper and zinc $(p<0.05)$ and insignificantly and positively correlated with arsenic content of the sediments that indicates that the copper and zinc occur as sulphide minerals. The mean concentrations of arsenic in the groundwater are $1.1793 \mu \mathrm{g} / \mathrm{L}$. The concentration of all the water samples is below the permissible limit of World Health Organization $(10 \mu \mathrm{g} / \mathrm{L})$. The arsenic content of groundwater shows the positive correlations with the arsenic, iron and copper concentrations of the sediments. This implies that the arsenic of groundwater derived from the geogenic source, like the dissolution of arsenic bearing minerals of the aquifer sediments-pyrite and arsenopyrite. The acidic nature, texture and minor quantities of total organic carbon are the factors that also influence the low arsenic enrichment in the investigated sediments and its release to the groundwater. The contemporary arsenic specification research works showed that As(III) the most common species in natural water and foodstuffs and the arsenic is inorganic from source in Bangladesh.
\end{abstract}

Keywords Low salinity $\cdot$ Arsenic $\cdot$ Total organic carbon $\cdot$ Acidic $\cdot$ Pyrite and arsenopyrite

\section{Introduction}

Arsenic is a trace element. It means that arsenic concentration exceeding the trace concentration limit in the environment may lead to toxic effects (Reza et al. 2010a; Sakala et al. 2011). The consumption of arsenic contaminated water can cause diabetes, black foot, skin cancer, gangrene, anuria, hyperpigmentation and other diseases (Awual et al. 2019; Moni et al. 2019; Li et al. 2010; Hughes 2002; Guo et al. 2007; Lai et al. 1994). The heavy metal arsenic is extensively spread in the atmosphere, marine and non-marine biota, plants, rocks, soils and hydrosphere (Rahman et al. 2019). The geochemical properties of arsenic are very complex as it naturally occurs various chemical alterations of arsenic in the environment, resulting from the amphoteric

Sudip Saha

sudips_geologist@yahoo.com

1 Department of Geology and Mining, University of Rajshahi, Rajshahi 6205, Bangladesh nature of arsenic ions (Sakala et al. 2011). Insoluble arsenic sulphides are oxidized through the As-bearing rock weathering, and thus, arsenites and arsenates are formed. Arsenic naturally occurs in the form of arsenates in the aerated sediments of the vadose zone, and nevertheless, another oxidation state (arsenites) may also occur under redox conditions (Cullen and Reimer 1989).

Arsenic is a significant contaminant of sediments, groundwater and soils in many parts of the planet earth. The world's most serious arsenic contamination issues concern the contamination of potable water in the sedimentary aquifers, especially in South East Asia (Bangladesh and West Bengal, India, Vietnam), Mexico, Argentina and the Great Hungarian Plains (Smedley and Kinniburgh 2002; Anawar et al. 2002; RoyChowdhury et al. 2002; Reza et al. 2011; Reza and Jean 2012; Liu et al. 2012; Hasan et al. 2020). The groundwater aquifers in various districts of Bangladesh have high arsenic concentrations (Rahman et al. 2018). The high levels of As in groundwater put Bangladesh under potential health hazard (Islam et al. 2017, 2018; Moni et al. 2019). 
Arsenic invades into the human food chain by the potable water and the food crops through the irrigation of As-contaminated water and soil (Reza and Jean 2012; Roychowdhury et al. 2005; Moni et al. 2019). The mean arsenic concentration of igneous and sedimentary rocks is $2 \mathrm{mg} \mathrm{kg}^{-1}$. In most rocks, the heavy metal arsenic content fluctuates from 0.5 to $2.5 \mathrm{mg} \mathrm{kg}^{-1}$ (Mandal and Suzuki 2002), although higher amounts were reported from clayey or argillaceous sediments and phosphorites. The mean arsenic concentration in European topsoil is $7.0 \mathrm{mg} \mathrm{kg}^{-1}$ (Stafilov et al. 2010; Sakala et al. 2011).

The Tista River is a braided river of Bangladesh which carries enormous amounts of sediment load. Teesta Kangse glacier is the source point of the Tista river that is situated $7,068 \mathrm{~m}$ above the mean sea level and flows towards the south through gorges and rapids in the Sikkim Himalaya, India (Meetei et al. 2007; Wiejaczka et al. 2014). A huge number of tributaries and distributaries nourished the Tista River. The total length of the Tista River is $309 \mathrm{~km}$ or 192 miles. The Tista river basin covers an area of $12,540 \mathrm{~km}^{2}$. Precipitation, melting glacier and snow and groundwater provide the water to the Tista river (Mukhopadhyay 1982). Eventually, it drains into the Brahmaputra River in Bangladesh (Fig. 1). Trivalent arsenic is reported as one of the most injurious components in water, and the toxicity of As(III) is sixty times greater than pentavalent arsenic or organic arsenic compounds (Jena and Raj 2008; Rahman et al. 2018). The present research aims to show the total arsenic content of the studies aquifer sediments and its spatial distribution.

Tectonically the investigated area located in the Rangpur Saddle. The deposits of active and older floodplain sediments of the Tista river constitute the shallow aquifer of the studied area. The stratigraphic succession of Rangpur saddle is shown in Table 1.

The main aims of the present research work are to determine the concentration of arsenic in the sedimentary deposits of the active floodplains of the Tista River and to ascertain the sources of arsenic in the study area.

\section{Materials and methods}

A detailed fieldwork was carried in 2014. To analyse the chemical composition of water 100 millilitre $(\mathrm{mL})$, polythene sample bottles were filled from tubewell. The water samples were acidified with required amounts of ultrapure nitric acid $\left(\mathrm{HNO}_{3}\right)$ for cation analysis. The sediment specimens were collected in polythene bags and preserved in the laboratory for chemical analyses. The sediment samples were first air-dried, dried afterwards in a thermostatically controlled oven at $105^{\circ} \mathrm{C}$ for overnight to remove the moisture and taken for different physico-chemical analysis.

\section{Determination of sediment $\mathrm{pH}$}

Ten grams of air-dried sediment sample were taken into a $100 \mathrm{~mL}$ plastic beaker, and $20 \mathrm{~mL}$ of distilled water was added for the pH measurements (Jackson 1973; Jaiswal 2011). The mixture was stirred for $10 \mathrm{~min}$ on a reciprocal shaker and left to stand for $30 \mathrm{~min}$. The mixture was shaken again for $2 \mathrm{~min}$, and the $\mathrm{pH}$ of the suspension was read using a pH metre

\section{Determination of sediment electrical conductance}

The electrical conductance (EC) of sediment is applied to express the salinity status of the sediments (Rhoades and Corwin 1990). Air-dried sediment specimen was measure with the aid of an electrical balance and was taken into a $150 \mathrm{~mL}$ plastic beaker, and afterwards, $50 \mathrm{~mL}$ of distilled water was added to the beaker. The mixture was shaken for $10 \mathrm{~min}$ on a reciprocal shaker and left to stand for $30 \mathrm{~min}$. The mixture was blended again for $2 \mathrm{~min}$, and the electrical conductance reading of the suspension was taken using an EC metre.

\section{Determination of sulphur content of sediment by turbidimetric method}

To measure extractable sulphur, the sediment samples of $10 \mathrm{~g}$ were extracted with $50 \mathrm{~mL}$ of $0.15 \%$ calcium chloride $\left(\mathrm{CaCl}_{2}\right)$ by shaking the contents in Nalgene bottles for $30 \mathrm{~min}$. The filtered extracts were examined for sulphur by turbidimetry method as explained by Subba Rao (1993). In turbidimetric procedure, sulphate in the extract was measured by converting it to barium sulphate suspension by using barium chloride fine crystals, and the resulting turbidity was measured at $340 \mathrm{~nm}$ using UV-visible spectrophotometer model Shimadzu UV-1800.

\section{Determination of total organic carbon of sediment by wet oxidation}

For sediments where there are no inorganic carbon forms are present, the total organic carbon is equivalent to total carbon content (Schumacher 2002).

$0.167 \mathrm{M}$ potassium dichromate: Oven-dried potassium dichromate of $49.04 \mathrm{~g}$ was measured with the help of a balance and made a solution of it using distilled water. Then, the solution is taken to a $1000 \mathrm{~mL}$ of volumetric flask and the flask is filled with distilled water.

Barium diphenylamine sulphonate (Indicator): $0.16 \mathrm{~g}$ reactant was dissolved in distilled water, warming carefully 


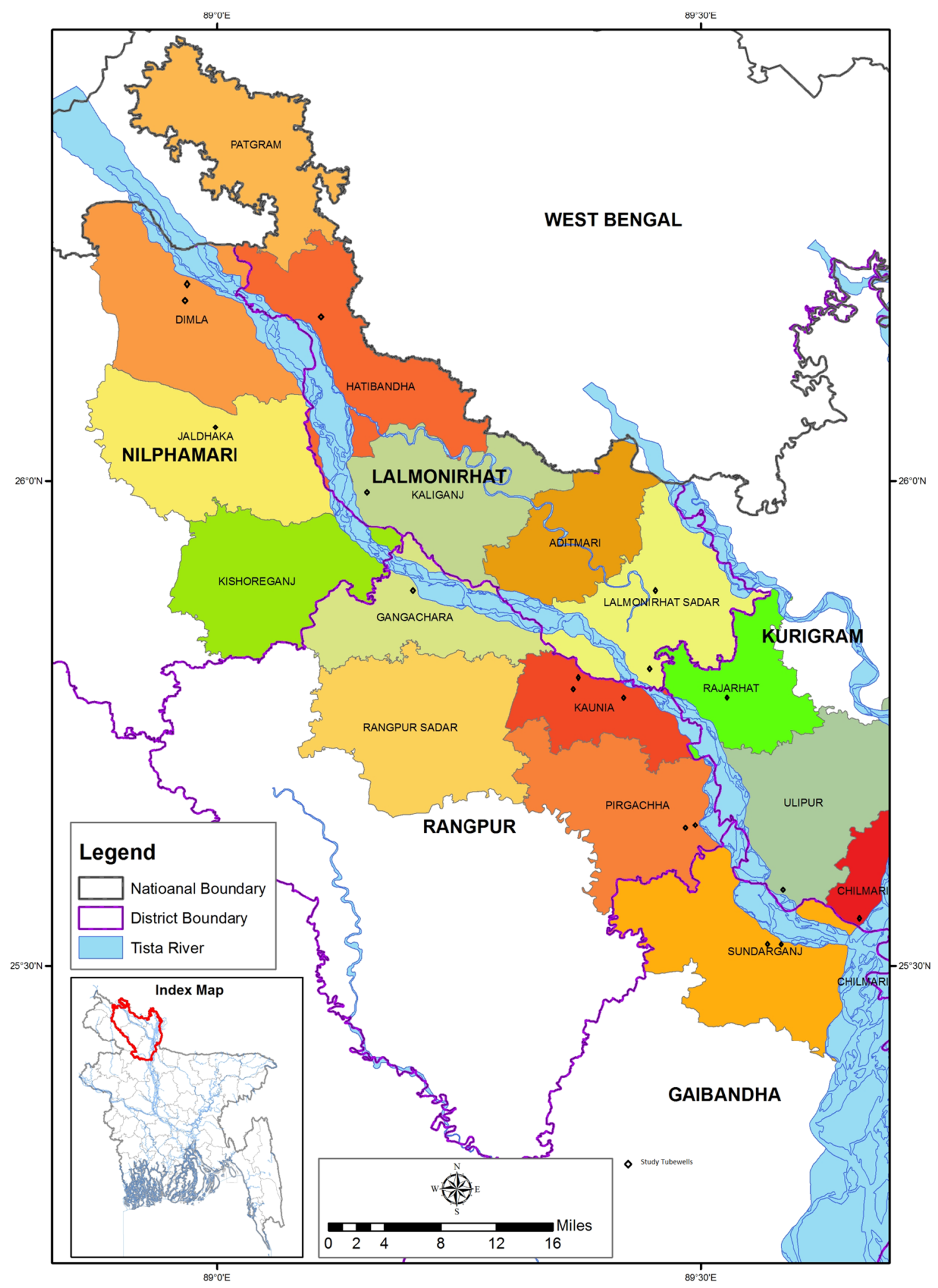

Fig. 1 Map of the study area (after Saha et al. 2019) 
Table 1 Stratigraphic succession of the Rangpur Saddle, Bangladesh. Modified after Hossain (1999), UNDP (1982)

\begin{tabular}{|c|c|c|c|}
\hline Age & Group/formation & Lithology & Thickness \\
\hline Recent to Sub-Recent & Alluvium & Sand, silt and clay & $53 \mathrm{~m}$ \\
\hline Late Pleistocene-Holocene & Tista Gravel & Gravels with sand and silt & 89 to $97 \mathrm{~m}$ \\
\hline Pleistocene & Barind Clay & Clay, sandy clay, yellow-brown sticky & $15 \mathrm{~m}$ \\
\hline $\begin{array}{l}\text { Middle Pliocene to Late Mio- } \\
\text { cene }\end{array}$ & Dupi Tila formation & Sandstone with subordinate pebble bed, grit bed and shale & $171 \mathrm{~m}$ \\
\hline Early Miocene & $\begin{array}{l}\text { Surma Group undifferentiated } \\
\text { (?) }\end{array}$ & $\begin{array}{l}\text { Fine to medium grain sandstone, sandy and silty shale, silt- } \\
\text { stone, and shale }\end{array}$ & $125 \mathrm{~m}$ \\
\hline Middle Eocene & $\begin{array}{l}\text { Tura sandstone (?) } \\
\text { formation }\end{array}$ & $\begin{array}{l}\text { Grey and white sandstone with subordinate greenish grey shale } \\
\text { and coal }\end{array}$ & $128 \mathrm{~m}$ \\
\hline Late Permian & Gondwana sediments & Feldspathic sandstone, shale, coal beds & $475 \mathrm{~m}$ \\
\hline Precambrian & Basement complex & Gneiss, schist, granodiorite, quartz diorite & \\
\hline
\end{tabular}

to aid dissolution. After cooling, the solution is transferred to $100 \mathrm{~mL}$ volumetric flask and distilled water was added to make the volume $100 \mathrm{~mL}$.

0.5 M ammonium iron (II) sulphate: $196 \mathrm{~g}$ of ammonium iron (II) sulphate reagent was dissolved in distilled water. Five millilitre of strong or concentrated sulphuric acid was mixed to the solution with care. After mixing the solution, it was transferred to $1000 \mathrm{~mL}$ volumetric flask and distilled water was added to make the total volume $1000 \mathrm{~mL}$.

$10 \mathrm{~mL}$ volume of potassium dichromate solution (a strong oxidizing agent) was added to a sample of dry, finely ground sediment $(0.9 \mathrm{~g})$. Concentrated $20 \mathrm{~mL}$ sulphuric acid was added to the reaction mixture to generate required heat. The flask was kept 30 min stand to complete the reaction. Organic carbon in the sediment was oxidized to $\mathrm{CO}_{2}$ by the dichromate, which itself is reduced. At final stage of the chemical reaction, the solution was weakening with distilled water. The dichromate which was not used to oxidize sediment carbon was determined by titrating against ammonium iron sulphate (a reducing agent). The organic carbon content of sediment was calculated from the unused dichromate in the solution.

To calculate total organic carbon, the following equation was used:

$\% C=\frac{4(b-t)}{b W}$

where the titration volume, $\mathrm{b}$ is in $\mathrm{mL}$ for the reagent blank, $\mathrm{t}$ is the titration volume for the sediment and $\mathrm{W}$ is the mass of the sediment.

\section{Determination of total nitrogen concentration of sediment}

Total nitrogen (TN) was measured by Kjeldhal digestion method (Black 1965). The method is consisting of heating of substance with sulphuric acid, which chemically breaks the organic substance by oxidation process to deliberate the reduced nitrogen as ammonium sulphate. In this stage, potassium sulphate is mixed to increase the boiling point of the medium from 337 to $373{ }^{\circ} \mathrm{C}$. The chemical decomposition of the sample is complete when initially very dark coloured medium has turned into clear and colourless form.

The solution was treated afterwards with minor amount of sodium hydroxide to transform the ammonium salt to ammonia. The amount of ammonia and thus the quantity of nitrogen present in the sample were measured by back titration. The end of the condenser was dipped into a solution of boric acid. The ammonia reacted with the boric acid and the rest of the acid was then titrated with a sodium carbonate solution by the application of methyl orange $\mathrm{pH}$ indicator.

Degradation: $\quad$ Sediment $+\mathrm{H}_{2} \mathrm{SO}_{4} \rightarrow\left(\mathrm{NH}_{4}\right)$ ${ }_{2} \mathrm{SO}_{4}+\mathrm{CO}_{2}+\mathrm{SO}_{2}+\mathrm{H}_{2} \mathrm{O}$.

Liberation of ammonia: $\left(\mathrm{NH}_{4}\right)_{2} \mathrm{SO}_{4}+2 \mathrm{NaOH} \rightarrow \mathrm{Na}_{2} \mathrm{SO}_{4}$ $+2 \mathrm{H}_{2} \mathrm{O}+\mathrm{NH}_{3}$.

Capture of ammonia: $\mathrm{B}(\mathrm{OH})_{3}+\mathrm{H}_{2} \mathrm{O}+\mathrm{NH}_{3} \rightarrow \mathrm{NH}_{4}{ }^{+}+\mathrm{B}$ $(\mathrm{OH})_{4}{ }^{-}$

Back-titration: $\mathrm{B}(\mathrm{OH})_{3}+\mathrm{H}_{2} \mathrm{O}+\mathrm{Na}_{2} \mathrm{CO}_{3} \rightarrow \mathrm{NaHCO}_{3}+\mathrm{N}$ $\mathrm{aB}(\mathrm{OH})_{4}+\mathrm{CO}_{2}+\mathrm{H}_{2} \mathrm{O}$.

In reality, this analysis is largely automated, and specific catalysts were used to accelerate the decomposition reaction. In recent times, titanium dioxide is used as a catalyst.

\section{Olsen bicarbonate extraction for determination of phosphorus content}

The cheapest and widely accepted method for determination of the concentration of phosphorus in sediments or soil is using $\mathrm{NaHCO}_{3}$ (Koralage et al 2015). An electrical balance was used to measure $2.5 \mathrm{~g}$ of air-dried sediment sample, which was put into a $250 \mathrm{~mL}$ shaking bottle, and $50 \mathrm{~mL}$ of Olsen's extracting solution (0.5 $\left.\mathrm{M} \mathrm{NaHCO}_{3}, \mathrm{pH} 8.5\right)$ was mixed to each bottle to achive 1:20 sediment to extractant 
ratio (Olsen et al 1954). The extraction was achieved by shaking the mixture on an electrical shaker for $30 \mathrm{~min}$. The suspension was filtered through Whatman no. 42 filter paper. Phosphorus concentration in the filtrate was determined colorimetrically by ascorbic acid method at $880 \mathrm{~nm}$ using UV-visible spectrophotometer model Shimadzu UV-1800.

\section{Analysis of sediments and water by atomic absorption spectrometer (AAS)}

Arsenic (both trivalent and pentavalent) in potable is harmful for human health (Rahman et al. 2018). The decomposition of arsenic bearing minerals that are present in the aquifer materials liberates arsenic to the groundwater. This study is conducted to determine the total arsenic and other heavy metal contents of the sediments of the aquifer materials of the investigated area. The sediment samples were analyzed for total (aqua-regia extractable) As, $\mathrm{Cu}, \mathrm{Zn}$ and Fe. For determination of aqua-regia extractable arsenic, each type of sediment sample was dried in an oven at $110{ }^{\circ} \mathrm{C}$ for $24 \mathrm{~h}$. For digestion, $0.5 \mathrm{~g}$ of sediment sample was weighed into a $250 \mathrm{ml}$ flask, to which $3.75 \mathrm{~mL}$ concentrated hydrochloric acid and $1.25 \mathrm{~mL}$ concentrated nitric acid were added (Joardar et al. 2005). The suspension was kept overnight in the flask and then it was refluxed for $2 \mathrm{~h}$, followed by dilution with deionized water to $50 \mathrm{~mL}$, stirring for $5 \mathrm{~min}$ and filtering ( $0.80 \mu \mathrm{m}$ filter) after cooling (Sakala et al. 2011). The filtrate was stored in a plastic bottle for analysis of arsenic using an AAS attached with a graphite furnace (Shimadzu AA6800). All acids used in present chemical analyses were of analytical grade. Standard QA/QC protocol was followed for water and sediment sample analysis, including replicate analysis ( 1 in every 5 samples) and checking of method blanks ( 1 in every 10 analysis). The acidified groundwater samples were analyzed to determine the concentration of arsenic in groundwater using AAS attached with a graphite furnace (Shimadzu AA6800).

\section{Results}

The geochemical study of the sediments of the aquifers of the investigated area reveals that among the analyzed heavy metals, iron is the most abundant metal and zinc is the less common metal (Table 2). The trend of the average concentrations can be shown as $\mathrm{Fe}>\mathrm{As}>\mathrm{Cu}>\mathrm{Zn}$. The acidic nature of the sediments indicates the climatic condition of the study area, oxic nature of the aquifer and derivation of the aquifer materials from the acidic rocks. The clay mineralogy of the $2 \mu \mathrm{m}$ sized particles reveals the dominance of the quartz and illite with minor amounts of chlorite, kaolinite. A rare As-bearing mineral, lavendulan, is identified which is a copper arsenate (Saha et al. 2018).

$\mathrm{pH}$ : The $\mathrm{pH}$ of the shallow aquifer sediments varies from 4.4 to 5.5 with a mean value of 4.93 . The low $\mathrm{pH}$ values indicate the acidic nature of the sediments. The highest value of $\mathrm{pH}$ was recorded in Votemari, Lalmonirhat and the value of $\mathrm{pH}$ is increasing in the downstream direction (Fig. 2a). The climatic parameters and parent materials of the sediments control its $\mathrm{pH}$ (Zhang et al. 2019). Acidic sediments are common in the areas of high rainfall. Moreover, the sand particles mainly comprise the sedimentary deposits of the study area.

Table 2 Results of physico-chemical analysis of the sediment samples of the study area

\begin{tabular}{|c|c|c|c|c|c|c|c|c|c|c|c|c|}
\hline Sl. No. & Location & Longitude & $\begin{array}{l}\text { EC } \\
\mathrm{ds} / \mathrm{m}\end{array}$ & $\mathrm{pH}$ & $\begin{array}{l}\text { TOC } \\
\%\end{array}$ & $\begin{array}{l}\mathrm{TN} \\
\%\end{array}$ & $\begin{array}{l}\mathrm{S} \\
\mathrm{mg} / \mathrm{kg}\end{array}$ & $\begin{array}{l}\mathrm{P} \\
\mathrm{mg} / \mathrm{kg}\end{array}$ & $\begin{array}{l}\mathrm{Cu} \\
\mathrm{mg} / \mathrm{kg}\end{array}$ & $\begin{array}{l}\mathrm{Zn} \\
\mathrm{mg} / \mathrm{kg}\end{array}$ & $\begin{array}{l}\mathrm{Fe} \\
\mathrm{mg} / \mathrm{kg}\end{array}$ & $\begin{array}{l}\text { As } \\
\mathrm{mg} / \mathrm{kg}\end{array}$ \\
\hline 1 & Tapakharibari & 88.950963 & 1.46 & 4.70 & 0.43 & 0.04 & 70.90 & 5.65 & 3.08 & 0.32 & $25,840.80$ & 2.99 \\
\hline 2 & Kharibari & 88.957194 & 2.22 & 4.40 & 0.71 & 0.06 & 104.57 & 5.23 & 2.26 & 1.08 & $24,367.40$ & 2.82 \\
\hline 3 & Dalia & 89.035134 & 0.44 & 4.60 & 0.20 & 0.02 & 7.34 & 5.52 & 1.96 & 0.38 & $27,875.20$ & 3.62 \\
\hline 4 & Doahni & 89.089465 & 0.55 & 5.40 & 0.16 & 0.01 & 5.71 & 4.45 & 0.22 & 0.52 & $25,688.80$ & 2.19 \\
\hline 5 & Votemari & 89.161820 & 1.14 & 5.50 & 0.16 & 0.01 & 46.45 & 4.86 & 0.40 & 0.34 & $25,384.80$ & 2.92 \\
\hline 6 & Laxmitari & 89.251106 & 2.39 & 4.60 & 0.12 & 0.01 & 118.21 & 15.03 & 5.62 & 0.80 & $26,682.80$ & 3.75 \\
\hline 7 & Mohipur & 89.252050 & 0.76 & 4.50 & 0.35 & 0.03 & 143.55 & 7.10 & 3.86 & 1.92 & $27,891.00$ & 5.77 \\
\hline 8 & Khuniagachh & 89.345713 & 0.96 & 4.70 & 0.16 & 0.01 & 37.27 & 4.19 & 0.44 & 0.24 & $24,841.00$ & 3.70 \\
\hline 9 & Marairhat & 89.409958 & 1.30 & 5.30 & 0.20 & 0.02 & 72.47 & 5.37 & 0.50 & 0.34 & $25,384.80$ & 2.91 \\
\hline 10 & Kaunia & 89.430932 & 0.47 & 4.70 & 0.20 & 0.02 & 2.58 & 6.14 & 0.34 & 0.52 & $27,115.20$ & 4.50 \\
\hline 11 & Shibdeb & 89.521515 & 1.75 & 5.40 & 0.62 & 0.05 & 71.04 & 7.49 & 3.04 & 0.48 & $27,781.80$ & 4.43 \\
\hline \multirow[t]{4}{*}{12} & Sundargonj & 89.536750 & 0.53 & 5.40 & 0.47 & 0.04 & 20.47 & 11.29 & 3.80 & 0.78 & $26,875.60$ & 2.64 \\
\hline & Mean & & 1.16 & 4.93 & 0.31 & 0.03 & 58.38 & 6.86 & 2.13 & 0.64 & $26,310.77$ & 3.52 \\
\hline & Median & & 1.05 & 4.70 & 0.20 & 0.02 & 58.68 & 5.59 & 2.11 & 0.50 & $26,261.80$ & 3.31 \\
\hline & Variance & & 0.42 & 0.16 & 0.04 & 0.00 & 2000.05 & 9.37 & 2.92 & 0.20 & $1,372,709.53$ & 0.92 \\
\hline
\end{tabular}


a

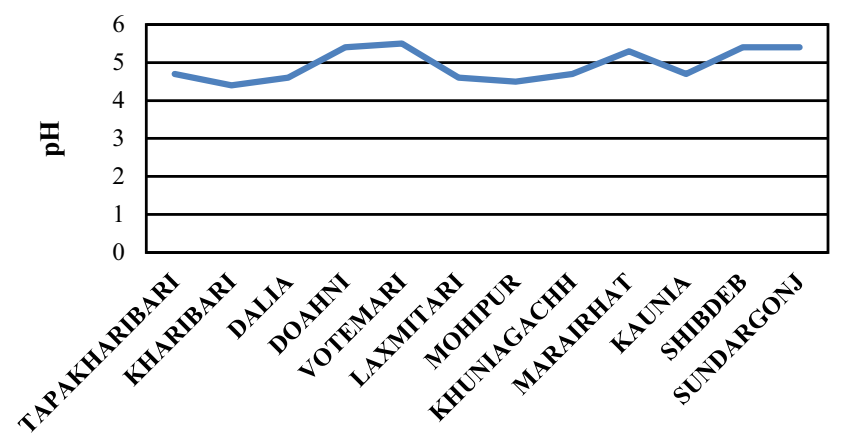

Location

c

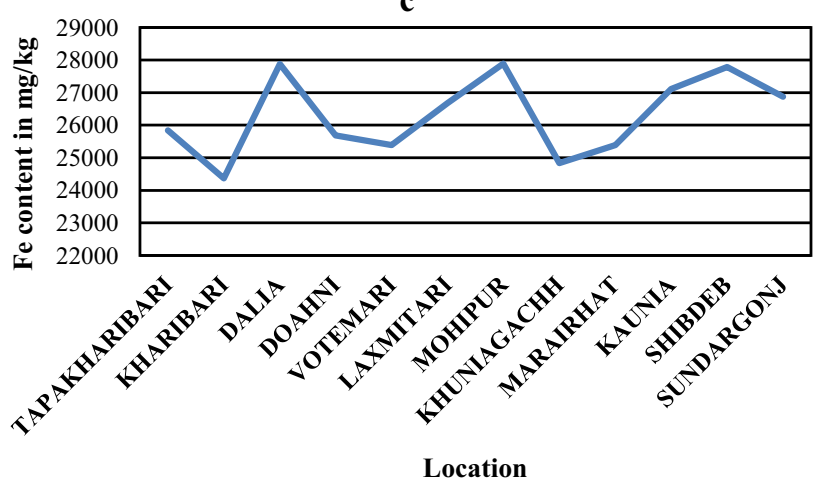

Location b

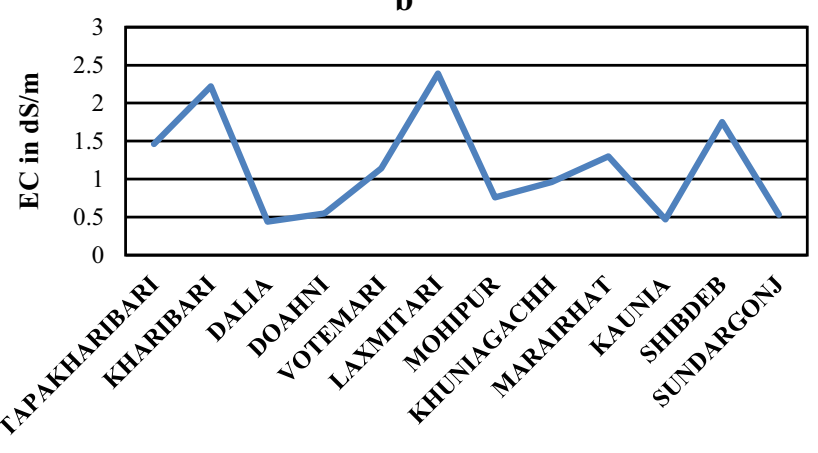

Location

d

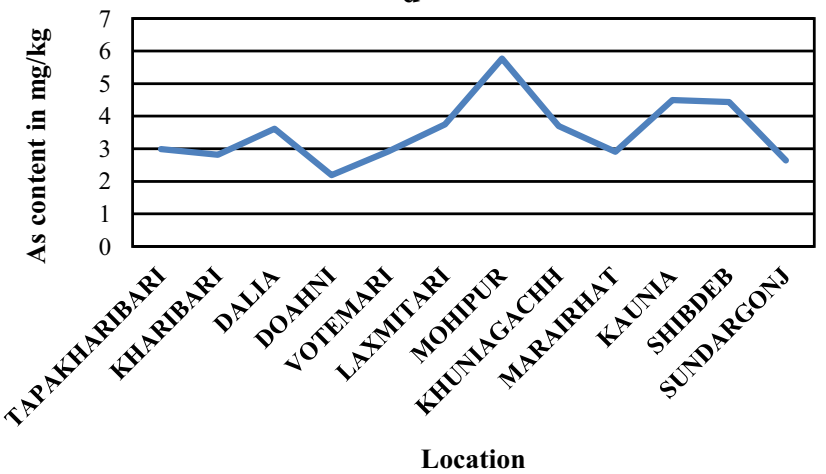

Fig. 2 a-d: Spatial distribution of $\mathrm{pH}, \mathrm{EC}$, iron and arsenic in the sediments of the study area

Electrical conductivity (EC): The maximum EC of the sediments of the study area is $2.39 \mathrm{ds} / \mathrm{m}$ which was recorded in Gangachara of Rangpur district. The lowest EC value of the sediments was found in Dalia, Nilhamari district that was $0.44 \mathrm{ds} / \mathrm{m}$ (Table 2). The magnitude of $\mathrm{EC}$ is decreasing with the fining nature of the sediments in the downstream direction (Saha et al. 2017). The mean EC value of the sediments was $1.16 \mathrm{ds} / \mathrm{m}$ that indicates very low or negligible effects of salinity of the sediments of the Rangpur division (SRDI 2010; Kumar et al. 2019).

Total Organic Carbon (TOC): The amount of total organic carbon varies from 0.117 to $0.709 \%$ which is very low. The median value of TOC $0.195 \%$ indicating that the sediments of Recent age contain low concentrations of TOC. The amount of TOC is slightly increasing in the distal part of the Tista Alluvial Fan.

Total Nitrogen (TN): The concentrations of nitrogen in the sediments of the investigated area are very low which ranges from 0.01 to $0.061 \%$. The average concentration of $\mathrm{N}$ is $0.0268 \%$. The distribution of the total nitrogen is lowest in the central part of the investigated area. The $86 \%$ recent sediment samples of the Brahmaputra floodplain have nitrogen deficiency (Moslehuddin 1993; Moslehuddin et al. 1997).
Sulphur (S): The average amount of sulphur is $58.38 \mathrm{mg} /$ $\mathrm{kg}$ that ranges from 2.58 to $143.55 \mathrm{mg} / \mathrm{kg}$. The maximum value of sulphur is high in the study area (SRDI 2010). The amount of sulphur is decreasing in the distal part of the fan that implies that the source of sulphur is the Himalayan Mountain Range.

Phosphorus (P): The average phosphorus content of the aquifer sediments is very low whose numerical value is $6.86 \mathrm{mg} / \mathrm{kg}$. The maximum amount of phosphorus is recorded as $15.03 \mathrm{mg} / \mathrm{kg}$ in Laxmitari, Gangachara, whereas the lowest value is $4.19 \mathrm{mg} / \mathrm{kg}$ in Khuniagachh, Lalmonirhat. The amount of phosphorus is increasing in the lower part of the floodplain area which indicates of the phosphorus may be derived from the anthropogenic activities, especially from phosphate fertilizer.

Copper $(\mathrm{Cu})$ : The median concentration of copper is $2.11 \mathrm{mg} / \mathrm{kg}$. The amount of copper varies from 0.22 to $5.62 \mathrm{mg} / \mathrm{kg}$ in the aquifer sediments of the study area.

Zinc ( $\mathrm{Zn})$ : The $\mathrm{Zn}$ content of the investigated sediment samples varies from 0.24 to $1.92 \mathrm{mg} / \mathrm{kg}$, with the average concentration of $0.643 \mathrm{mg} / \mathrm{kg}$. The optimum $\mathrm{Zn}$ content is $1.135 \mathrm{mg} / \mathrm{kg}$, only one of the sediment samples exceeds the optimum Zn content (BARC 2018).

Iron $(\mathrm{Fe})$ : Chemical weathering and erosion of mountain belts influence the distribution of trace metal influx to the 
ocean, sediments carried by the rivers and groundwater flow (Dowling et al. 2003; Zahid et al. 2008). The concentrations of iron vary from $24,367.4$ to $27891 \mathrm{mg} / \mathrm{kg}$ with the mean concentrations of $26,310.77 \mathrm{mg} / \mathrm{kg}$. The sediments of the investigated area are characterized by the fining nature in the downstream direction (Saha et al., 2017). The concentrations of total iron increase in the downstream direction of the Tista River with the fining natures of the sediments. The iron-bearing minerals include biotite, hornblende, magnetite and hematite.

Arsenic (As): The mean concentration of total arsenic is $3.52 \mathrm{mg} / \mathrm{kg}$ where the maximum and minimum concentrations are $5.77-2.19 \mathrm{mg} / \mathrm{kg}$. The finer sediments contain more arsenic in the downstream direction of the study area as the amount of iron also increases.

\section{Correlation coefficient matrix of sediment parameters}

The electrical conductance (EC) shows significant positive correlation with sulphur $(p<0.05)$ and insignificant positive correlations with total organic carbon, total nitrogen, phosphorus, copper and zinc (Table 3). Total organic carbon is significantly positively correlated with total nitrogen $(p<0.01)$ and insignificantly positively correlated with the sulphur, copper and zinc (Fig. 3).

The study reveals insignificant positive correlations of total nitrogen with the sulphur, copper and zinc. Sulphur is significantly correlated with copper and zinc $(p<0.05)$ (Fig. 3c and e) and insignificantly and positively correlated with arsenic content of the sediments (Table 3) that indicates that the copper and zinc occur as sulphide minerals. The element $\mathrm{P}$ shows significant positive correlation with copper $(p<0.01)$ that implies that both the elements $(\mathrm{Cu}$ and $\mathrm{P}$ ) might have derived from the chemical dissolution of copper phosphate minerals. Arsenic (Fig. 3f) is significantly positively correlated with iron $(p<0.05)$. This observation also implies that the As was absorbed by the iron-bearing minerals such as biotite, hornblende and oxides of iron like hematite, magnetite and iron hydroxides at the time of the deposition of the aquifer sediments (Awual et al. 2019; Moni et al. 2019; Yang et al. 2017; Wang and Giammar 2015; Reza and Jean 2012; Bhattacharyya and Mukherjee 2008).

The positive correlation of arsenic with iron shows that the arsenic is released by the dissolution of pyrite and arsenopyrite to the sediments of the study area. The coarser sediments contain less arsenic, while the finer sediments have higher arsenic concentration. The study area is dominated by the sand and pebbles with minor amount of silts and clay that contribute less amounts of arsenic to the sediments.

\section{Clay mineralogy of the sediments}

The XRD analyses of the sediments show that the illite and quartz are major minerals of the clay-sized particles of the investigated area. Chlorite, kaolinite and feldspar comprise $9.80 \%$ of the sediments. Illite is identified by peak $10 \AA$ (001) and distinguished from mica by the narrowing nature of the diffractograms (Zahid et al. 2008). Chlorite is identified by the $14 \AA$ peak, and kaolinite is recognized at $7 \AA$. Lavendulan [ $\mathrm{Na}, \mathrm{Ca}, \mathrm{Cu}_{5}\left(\mathrm{AsO}_{4}\right)_{4} \mathrm{Cl} .5 \mathrm{H}_{2} \mathrm{O}$ ] mineral group was detected at basal reflections 10.054-10.072 $\AA$ in small quantities. The mineral was identified in two places of the area of investigation and they are, namely Shutibari and Sundarganj. Lavendulan is a rare copper arsenate mineral (Saha et al. 2018).

\section{Arsenic concentration of groundwater and its correlation with sediment}

The $\mathrm{pH}$ of groundwater varies from 6.20 to 7.40 of the study areas. The mean electrical conductance of the groundwater samples is $361.58 \mu \mathrm{S} / \mathrm{cm}$. The mean abundance of major cations is $\mathrm{Na}^{+}>\mathrm{Ca}^{+2}>\mathrm{Mg}^{+2}>\mathrm{K}^{+,}$whereas the major anions is
Table 3 Pearson correlation coefficient matrix of sediment parameters

\begin{tabular}{lrrllllllll}
\hline & EC & $\mathrm{pH}$ & $\mathrm{TOC}$ & $\mathrm{TN}$ & $\mathrm{S}$ & $\mathrm{P}$ & $\mathrm{Cu}$ & $\mathrm{Zn}$ & $\mathrm{Fe}$ & $\mathrm{As}$ \\
\hline $\mathrm{EC}$ & 1.000 & & & & & & & & & \\
$\mathrm{pH}$ & -0.218 & 1.000 & & & & & & & & \\
$\mathrm{TOC}$ & 0.374 & -0.080 & 1.000 & & & & & & & \\
$\mathrm{TN}$ & 0.351 & -0.146 & $0.987^{* *}$ & 1.000 & & & & & & \\
$\mathrm{~S}$ & $0.681^{*}$ & -0.402 & 0.321 & 0.320 & 1.000 & & & & & \\
$\mathrm{P}$ & 0.367 & -0.059 & 0.002 & 0.016 & 0.337 & 1.000 & & & & \\
$\mathrm{Cu}$ & 0.464 & -0.313 & 0.336 & 0.357 & $0.615^{*}$ & $0.829^{* *}$ & 1.000 & & & \\
$\mathrm{Zn}$ & 0.074 & -0.413 & 0.318 & 0.317 & $0.668^{*}$ & 0.280 & 0.517 & 1.000 & & \\
$\mathrm{Fe}$ & -0.327 & -0.041 & 0.000 & 0.045 & -0.007 & 0.385 & 0.445 & 0.305 & 1.000 & \\
$\mathrm{As}$ & -0.063 & -0.436 & 0.025 & 0.046 & 0.421 & 0.139 & 0.303 & 0.544 & $0.648^{*}$ & 1.000 \\
\hline
\end{tabular}

*Correlation is significant at the 0.05 level (2-tailed)

**Correlation is significant at the 0.01 level (2-tailed) 
Fig. 3 Correlation of different chemical parameters of the sediments of the studied area
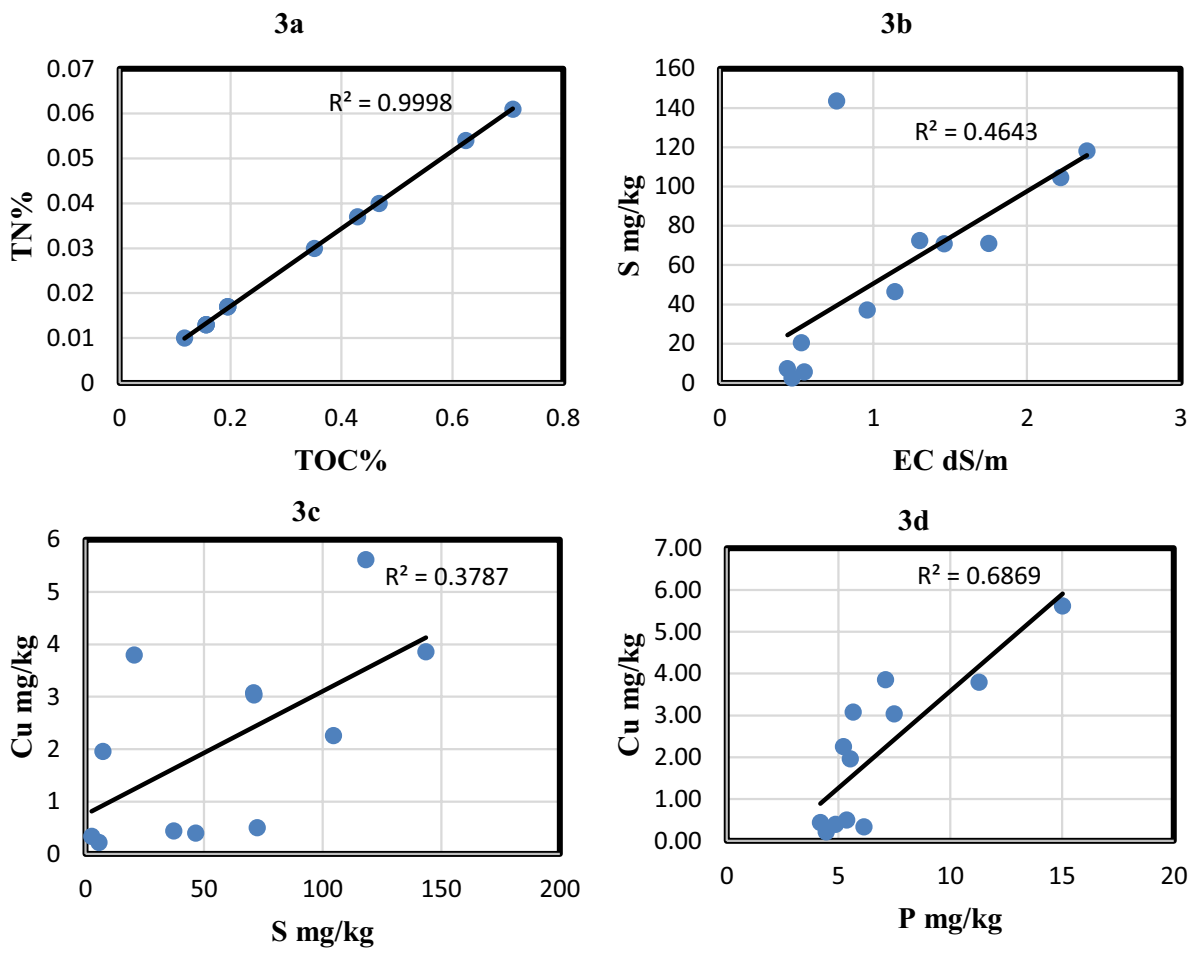

$3 \mathbf{e}$

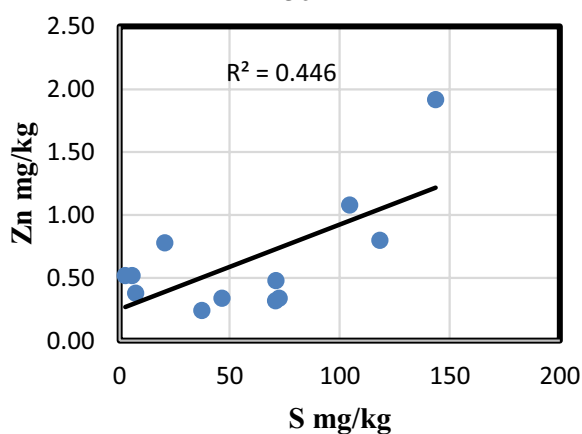

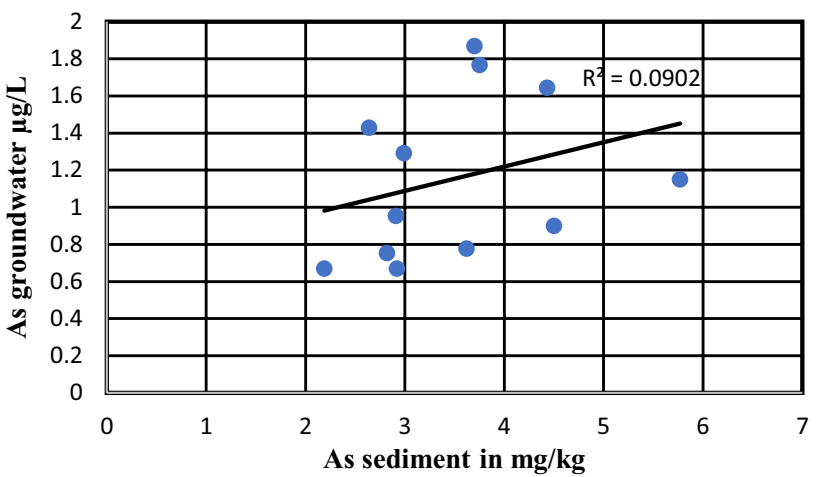

Fig. 4 The positive correlation between As sediment and As groundwater
$\mathrm{HCO}_{3}{ }^{-}>\mathrm{Cl}^{-}>\mathrm{SO}_{4}{ }^{-2}$ (Saha et al. 2019). Arsenic concentrations vary from 0.6704 to $1.8692 \mu \mathrm{g} / \mathrm{L}$ with mean content of $1.1793 \mu \mathrm{g} / \mathrm{L}$. The concentration of all the water samples is below the permissible limit of WHO $2008(10 \mu \mathrm{g} / \mathrm{L})$. The arsenic concentration of groundwater shows the positive correlations with the arsenic, iron and copper concentrations of the sediments (Fig. 4). This implies that the arsenic of groundwater derived from the geogenic source, like the dissolution of arsenic bearing minerals of the aquifer sediments—pyrite and arsenopyrite.

\section{Discussion}

The Tista sediments are dominated sand deposits laden with pebbles and cobbles. The fine grain sediments comprise minor portion of the sedimentary successions. The mineralogical analyses decipher that the silica or quartz is 
the major mineral with illite and kaolinite in accessory in amount, i.e. tectosilicates and phyllosilicates are common. In some places, the colour mottling was reported due to admixture of dark colour minerals with the light coloured minerals. The dark coloured minerals mainly carry the heavy metals like in their crystal lattices. The heavy metal arsenic can be found both in oxidizing and reducing conditions at $\mathrm{pH}$ values ranging from 6.5 to 8.5 (Asif and Chen 2017). The arsenic is principally derived from the geogenic sources and found in the alluvial sediments of Holocene age, especially in the low lying land (Joardar et al. 2005; Karim 2000). The floodplain sediments of the Brahmaputra, Ganges and Meghna are moderately and the delta plains are severely contaminated by arsenic (up to hundreds $\mathrm{mg} / \mathrm{kg}$ ) (Ahmed et al. 2004; Reza et al. 2010b). The maximum amounts of arsenic are reported from the fine grained sediments, especially from the clay fractions and organic matter in Bangladesh (Joardar et al. 2005; Reza et al. 2010b). The arsenic concentrations increase in the downstream directions of the study area with the finning nature of the sediments, i.e. with the elevated amounts of silt and clay (Fig. 2d). The arsenic content of the para- and ferromagnetic minerals from the upstream deposits of the Tista river ranged from 9 to $80 \mathrm{mg} / \mathrm{kg}$ (Bhattacharyya and Mukherjee 2008) which is relatively high and might have resulted from the fractional separation of the para- and ferromagnetic minerals from the sediments. The contemporary research work shows that the arsenic which is reported from the groundwater and foodstuffs are of inorganic origin in Bangladesh and more harmful for the human health (Awual et al. 2019; Rahman et al. 2019). The movement of the dominant species As(III) is more frequent in the groundwater from a huge areas of Bangladesh (Reza et al. 2010b; Thoral et al. 2005).

The dominant factors that influence the concentration of arsenic in the sediments are the parent rocks and human activities. The factors such as climate, the organic and inorganic components of the sediments and redox potential status also affect the level of arsenic in the sediments and soils (Mandal and Suzuki 2002).

The variation of total organic carbon (TOC) is observed (Table 2) and these differences resulted from the growth of vegetation matters in the marshy lands and litter input (Guo et al. 2018). The elevated amounts of total organic carbon resulted from the growth of larger amounts of plants for prolonged interval and represent the periods of non-deposition.

The redox potential is considered as one of the most prominent factors that influence arsenic retention and mobilization in in sediments (Bostick et al. 2004; O'Day el al. 2004; Wang and Giammar 2015). Due to shallow water depth, $\mathrm{O}_{2}$ penetration may lead to more oxic conditions in the Tista River. Moreover, $\mathrm{O}_{2}$, microbial activities also play a vital role in regulating redox conditions in sediments. The presence of total organic matter (up to $1 \%$ ) may produce adequate nutrients for microbes hence stimulating microbialmediated reduction of elements in the Tista river. The positive correlation of arsenic with iron discloses that the arsenic is delivered by the dissolution of pyrite and arsenopyrite to the sediments of the research area. The X-ray diffraction study of the $2 \mu \mathrm{m}$ size sediments contains rare amounts of lavendulan, which is a rare copper arsenate (Saha et al. 2018). The mineral sampleite $\left(\mathrm{NaCaCu}_{5}\left(\mathrm{PO}_{4}\right) 4 \mathrm{Cl} \cdot 5 \mathrm{H}_{2} \mathrm{O}\right)$ is a member of the lavendulan group that might have contribute $\mathrm{Cu}$ and $\mathrm{P}$ in the sediments. $\mathrm{Fe}, \mathrm{Mn}, \mathrm{SO}_{4}{ }^{2-}$ and $\mathrm{S}^{2-}$ are the main carrier of arsenic in the sediments of Bangladesh (Reza et al. 2010b).

The arsenic concentration of groundwater shows the positive correlations with the arsenic, iron and copper concentrations of the sediments. This implies that the arsenic of groundwater derived from the geogenic source, like the dissolution of arsenic bearing minerals of the aquifer sediments-pyrite and arsenopyrite. The lower concentrations of arsenic in sediments resulted from the lower $\mathrm{pH}$ values and low TOC content of the sediments.

\section{Conclusion}

The present study reveals that the sediments of the study area are acidic in nature which reflects that they are derived from acid rocks. The sand particles comprise the major part of the deposits. The mean EC value of the sediments was $1.16 \mathrm{ds} / \mathrm{m}$ that indicates very low or negligible effects of salinity of the sediments of the Rangpur division. The recent deposits of the Tista River contain low amounts of total organic carbon. The less amount of total organic carbon and acidic nature of the sediments are the factors that controls the amount of arsenic in the aquifer sediments as well as release in groundwater. The average concentration of $\mathrm{N}$ is $0.0268 \%$. The concentrations of iron vary from $24,367.4$ to $27891 \mathrm{mg} / \mathrm{kg}$ with the mean concentrations of $26,310.77 \mathrm{mg} /$ $\mathrm{kg}$. Sulphur is significantly, positively correlated with copper and zinc $(p<0.05)$ and insignificantly and positively correlated with arsenic content of the sediments that indicates that the copper and zinc occur as sulphide minerals. The geochemical analysis of the sediments manifests that the arsenic is positively correlated with iron. The positive relationship of arsenic with iron shows that the arsenic is carried by the compounds of iron in recent riverine sediments of Bangladesh (Nickson et al. 2000; McArthur et al. 2001; Ravenscroft 2001; Reza et al. 2010b). The arsenic concentration of groundwater shows the positive correlations with the arsenic, iron and copper concentrations of the sediments. This implies that the arsenic of groundwater derived from the geogenic source, like the dissolution of arsenic bearing minerals of the aquifer sediments-pyrite and arsenopyrite. 
The average concentrations of arsenic in the groundwater are $1.1793 \mu \mathrm{g} / \mathrm{L}$. The concentration of all the water samples is below the permissible limit of WHO $(10 \mu \mathrm{g} / \mathrm{L})$. The recent arsenic specification studies revealed that the arsenic is inorganic of origin and As(III) the most dominant species in the groundwater and foodstuffs in Bangladesh.

Acknowledgements The authors are pleased to express due thanks to Professor Dr. Golam Shabbir Sattar, Ex-Chairman, Professor Dr. Khondaker Emamul Haque, Ex-Chairman and Professor Dr. Md. Sultan-ul-Islam, Chairman Department of Geology and Mining, University of Rajshahi, Bangladesh for arranging the research work. The authors are grateful to Soil Resource Development Institute (SRDI), Dhaka for providing generous approval to analyze the sediment specimens in the Laboratory of SRDI. Special thanks to Professor Dr. Hasan Ahmad, Ex-Director, Central Science Laboratory (CSL), University of Rajshahi, for his kind consent to analyze samples in the CSL. We are also thankful to Mr. Md. Azizul Alam for his kind preparation of the map of the study area.

Financial Disclosure statement The author(s) received no specific funding for this work.

\section{Declarations}

Conflict of interest No conflict of interest.

Open Access This article is licensed under a Creative Commons Attribution 4.0 International License, which permits use, sharing, adaptation, distribution and reproduction in any medium or format, as long as you give appropriate credit to the original author(s) and the source, provide a link to the Creative Commons licence, and indicate if changes were made. The images or other third party material in this article are included in the article's Creative Commons licence, unless indicated otherwise in a credit line to the material. If material is not included in the article's Creative Commons licence and your intended use is not permitted by statutory regulation or exceeds the permitted use, you will need to obtain permission directly from the copyright holder. To view a copy of this licence, visit http://creativecommons.org/licenses/by/4.0/.

\section{References}

Ahmed KM, Bhattacharya P, Hasan MA, Akhter SH, Alam S, Bhuyian MAH, Imam MB, Khan AA, Sracek O (2004) Arsenic enrichment in groundwater of the alluvial aquifers in Bangladesh: an overview. Appl Geochem 19:181-200

Anawar HM, Akai J, Mostafa KM, Safiullah S, Tareq SM (2002) Arsenic poisoning in groundwater: Health risk and geochemical sources in Bangladesh. Environ Int 27:597-604

Asif Z, Chen Z (2017) Removal of arsenic from drinking water using rice husk. Appl Water Sci 7:1449-1458. https://doi.org/10.1007/ s13201-015-0323-x

Awual MR, Hassan MM, Asiri AM, Rahman MM (2019) Cleaning the arsenic $(\mathrm{V})$ contaminated water for safe-guarding the public health using novel composite material. Composite Part B 171:294-301

BARC (Bangladesh Agricultural Research Council) (2018) Fertilizer Recommendation Guide-2018: Bangladesh Agricultural Research Council (BARC), Farmgate, Dhaka, Bangladesh

Bhattacharyya D, Mukherjee PK (2008) Contamination of shallow aquifers by arsenic in upper reaches of Tista river al
Siliguri-Jalpaiguri area, India. Environ Geol 169:188-193. https:// doi.org/10.1007/s00254-008-1450-6

Black CA (1965) Total nitrogen. In methods of soil analysis, Part 2. Lie Madison Wis. American Society of Agronomy, pp 1149-1178

Cullen WR, Reimer J (1989) Arsenic speciation in the environment. Chem Rev 8:713-789

Dowling CB, Poreda RJ, Basu AR (2003) The groundwater geochemistry of the Bengal Basin: Weathering, chemisorption, and trace metal flux to the ocean. Gecochemica Et Cosmochimica Acta 67(12):2117-2136

Guo HM, Stuben D, Berner Z (2007) Adsorption of arsenic (III) and arsenic (V) from groundwater from siderite as the adsorbent. J Coll Interface Sci 315(1):47-53

Guo P, Sun Y, Su H, Wang M, Zhang Y (2018) Spatial and temporal trends in total organic carbon (TOC), black carbon and total nitrogen $(\mathrm{TN})$ and their relationships under different planting patterns in a restored coastal mangrove wetland: case study in Fujian, China. Chem Spec Biodivers 30(1):47-56. https://doi.org/ 10.1080/09542299.2018.1484673

Hasan AB, Reza AHMS, Kabir S, Siddique MAB, Ahsan MA, Akbor MA (2020) Accumulation and distribution of heavy metals in soil and food crops around the ship breaking area in southern Bangladesh and associated health risk assessment. SN Appl Sci 2:155. https://doi.org/10.1007/s42452-019-1933-y

Hossain I (1999) Lithofacies and petrographic study of the Gondwana Group in the boreholes GDH-40 and GDH-43, Barapukuria Basin, Dinajpur, Bangladesh. An unpublished M.Sc thesis, Department of Geology and Mining, University of Rajshahi

Hughes MF (2002) Arsenic toxicity and potential mechanisms of action. Toxicol Lett 133:1-16

Islam ARMT, Shen SH, Bodrud-Doza M (2017) Assessment of Arsenic health risk and source apportionment of groundwater pollutaants using multivariate statistical techniques in ChapaiNawabganj District, Bangladesh. J Geol Soc India 90:239-248. https://doi.org/10.1007/s12594-017-0705-9

Islam MM, Karim MR, Zheng X, Li X (2018) Metal and metalloid pollution in soil, water and foods in Bangladesh: a critical review. Int J Environ Res Public Health 15:2825. https://doi.org/ 10.3390/ijerph15122825

Jackson ML (1973) Soil chemical analysis. Prentice-Hall Inc., Engiewood Cliffs, NJ

Jaiswal PC (2011) Soil, plant and water analysis. Kalyani Publishers, India

Jena BK, Raj CR (2008) Gold nanoelectrode ensembles for the simultaneous electrochemical detection of ultra trace arsenic, mercury and copper. Anal Chem 80:4836-4844

Joardar JC, Rashid MH, Huq SMI (2005) Adsorption of Arsenic (As) in soils and in their Clay fraction. Dhaka Univ J Biol Sci 14(1):51-61

Karim MM (2000) Arsenic in groundwater and health problem in Bangladesh. Wat Res 34:304-310

Koralage SA, Weerasinghe P, Silva NRN, De Silva CS (2015) The determination of phosphorus in soil: a quick and simple method. OUSL J 8:1-17

Kumar U, Mitra JR, Mia MY (2019) Seasonal study on soil salinity and its relation to other properties at Satkhira district in Bangladesh. Progress Agric 30(2):157-164

Lai MS, Hsueh YM, Chen CJ, Shyu MP, Chen SY, Kuo TL et al (1994) Ingested inorganic arsenic and prevalence of diabetes mellitus. Amer J Epidemiol 139:484-492

Li ZJ, Deng SB, Yu G, Huang J, Lim VC (2010) As (V) ans As (III) removal from water by a Ce-Ti oxide adsorbent: behavior and mechanism. Chem Eng J 161:106-113

Liu CC, Maity JP, Jean JS, Reza AHMS, Li Z, Nath B, Lee MK, Lin $\mathrm{KH}$ (2012) Geochemical characteristics of the mud volcano fluids in southwestern Taiwan and their possible linkage to elevated 
arsenic concentration in Chianan plain groundwater. Environ Earth Sci 66(5):1513-1523

Mandal BK, Suzuki KT (2002) Arsenic round the world: a review. Talanta 58:201-235

McArthur JM, Ravenscroft P, Safiullah S, Thirlwall MF (2001) Arsenic in groundwater: testing pollution mechanism for sedimentary aquifers in Bangladesh. Water Resour Res 37:109-117

Meetei LI, Pattanayak SK, Bhaskar A, Pandit MK, Tandon SK (2007) Climatic inprints in Quaternary valley fill deposits of the middle Teesta valley. Sikkim Himalaya Quater Int 159(1):32-46

Moni SA, Satter GS, Reza AHMS, Ahsan MA (2019) Hydrogeochemistry and Arsenic contamination of shallow aquifers in Bidyananda and Nazimkhan Unions, Rajarhat Upazila, Kurigram, Bangladesh. J Geol Soc India 94:395-404. https://doi.org/10. 1007/s12594-019-1327-1

Moslehuddin AZM (1993) A detailed survey of the fertility status of Bangladesh Agricultural University Farm Soils: M.Sc. thesis, Soil Science Department, Bangladesh Agricultural University, Mymensingh, Bangladesh

Moslehuddin AZM, Laizoo S, Egashira K (1997) Fertility status of Bangladesh soils-A review. J Faculty Agric Kyushu University 41(3,4):257-267

Mukhopadhyay SC (1982) The Tista basin: a case study in fluvial geomorphology, New Delhi

Nickson RT, McArthur JM, Ravenscroft P, Burgess WG, Ahmed KM (2000) Mechanism of arsenic release to groundwater. Bangladesh and West Bengal Appl Geochem 15:403-413

Olsen SR, Cole CV, Watanabe FS, Dean LA (1954) Estimation of available phosphorus in soils by extraction with $\mathrm{NaHCO}_{3}$. USDA Cir.939. U.S. Washington

Rahman MM, Hossain MM, Arshad MN, Awual MR, Asiri AM (2019) Arsenic sensor development based on modification with (E)-N' (2-nitrobenzylidine) - benzenesulfonohydrazide: a real sample analysis. New J Chem 43:9066. https://doi.org/10.1039/C9NJ0 $1567 \mathrm{~A}$

Rahman MM, Hussein MA, Arshad MN, Aly KI, Asiri AM (2018) Thermally stable hybrid polyarylidene (azomethine-ether)s polymers (PAAP): an ultrasensitive arsenic (III) sensor approach. Des Monomer Polym 21(1):82-98. https://doi.org/10.1080/15685551. 2018.1471793

Ravenscroft P (2001) Distribution of groundwater arsenic in Bangladesh related to geology. In: Jacks G, Bhattacharya P, Khan AA (Eds.) Groundwater Arsenic contamination in the Bengal delta plains of Bangladesh. Proceedings of KTH-Dhaka University Seminar. KTH Special Publications, TRITA-AMI report 3084:41-56

Reza AHMS, Jean JS (2012) Vertical distribution and mobilization of arsenic in shallow alluvial aquifers of Chapai-Nawabganj district, northwestern Bangladesh. J Geol Soc India 80:531-538

Reza AHMS, Jean JS, Lee MK, Luo SD, Bundschuh J, Li HC, Yang HJ (2011) Interrelationship of TOC, As, Fe, Mn, Al and $\mathrm{Si}$ in shallow alluvial aquifers in Chapai-Nawabganj, Northwestern Bangladesh: implication for potential source of organic carbon. Environ Earth Sci 63(5):955-967

Reza AHMS, Jean JS, Lee MK, Yang HJ, Liu CC (2010a) Arsenic enrichment and mobilization in the alluvial aquifers of the ChapaiNawabganj district, Bangladesh. A Geochem Stat Stud Appl Geochem 25:1280-1289

Reza AHMS, Jean JS, Yang HJ, Lee MK, Woodall B, Liu CC, Lee JF, Luo SD (2010b) Occurrence of arsenic in core sediments and groundwater in the Chapai-Nawabganj district, northwestern Bangladesh. Water Res 44:2021-2037

Rhoades JD, Corwin DL (1990) Soil electrical conductivity: effects of soil properties and application to soil salinity appraisal. USDAARS U.S. Salinity Laboratory, Commun. Soil Sci Plant Anal $21: 837-860$
Roychowdhury T, Tokunaga H, Uchino T, Ando M (2005) Effects of arsenic contaminated irrigation water on agricultural land soil and plants in West Bengal, India. Chemosphere 58:799-810

Roychowdhury T, Uchino T, Tokunaga H, Ando M (2002) Arsenic and other heavy metals in soils from an arsenic affected area of West Bengal, India. Chemosphere 49:605-618

Saha S, Reza AHMS, Roy MK (2019) Hydrochemical evaluation of the groundwater quality of the Tista floodplain, Rangpur. Bangladesh. Appl Water Sci 9:198

Saha S, Roy MK, Reza AHMS (2017) Textural Characteristics of the Sediments of the Tista River, Rangpur, Bangladesh. J Life Earth Sci 12:73-79, JLES, RU

Saha S, Roy MK, Reza AHMS (2018) Clay mineralogical studies to access provenance in riverine sequences, the Tista River, Rangpur, Bangladesh. In: International conference of geosciences and environment (ICGE 2018) September 08-09, 2018, Department of Geology and Mining, University of Rajshahi, Rajshahi-6205, Bangladesh

Sakala J, Vacha R, Cechmankova J (2011) Evaluation of arsenic occurrence in agricultural soils of the Bohemian Forest region. Silva Gabreta 17(2-3):55-67

Schumacher BA (2002) Methods for the determination of total organic (TOC) $n$ soils and sediments: USEPA, Las Vegas

Smedley PL, Kinniburgh DG (2002) A review of the source, behaviour and distribution of arsenic in natural Water. Appl Geochem 17:517-568

SRDI (2010) Saline soils of Bangladesh: soil resources development institute, SRMAF project, Ministry of Agriculture, Dhaka, Bangladesh

Stafilov T, Aliu M, Sajn R (2010) Arsenic in surface soils affected by mining and metallurgical processing in K. Mitrovica Region, Kosovo. Int J Environ Res Public Health 7:4050-4061

Subba Rao NS (1993) Biofertilizers in agriculture and forestry. International Science Publisher: New York, 3rd Ed

Thoral S, Rose J, Garnier JM, Van Geen A, Refait P, Traverse A, Fonda E, Nahon D, Bottero JY (2005) XAS study of iron and arsenic speciation during F(II) oxidation in the presence of As(III). Environ Sci Technol 39:9478-9485

UNDP (United Nations Development Programme) (1982) Groundwater survey: the hydrogeological conditions of Bangladesh. UNDP Technical Report DP/UN/BGD-74-009/1

Wang L, Giammar DE (2015) Effects of $\mathrm{pH}$, dissolved oxygen and aqueous ferrous iron on the adsorption of arsenic to lepidocrocite. J Colloid Interface Sci 448:331-338

Wiejaczka L, Bucala A, Sarkar S (2014) Human role in shaping the hydromorphology of the Himalayan rivers: study of the Tista River in Darjeeling Himalaya. Curr Sci 106(5):717-724

World Health Organization (WHO) (2008) Guidelines for drinkingwater quality: Third Edition, Incorporating the First and Second addendum, Vol. 1, Recommendations, World Health Organization, Geneva, Switzerland, p 668

Yang XT, Xia L, Li JL, Dai M, Yang GC, Song SX (2017) Adsorption of As(III) on porous hematite synthesized from goethite concentrate. Chemosphere 169:188-193

Zahid A, Hassan MQ, Breit GN, Balke KD, Flegr M (2008) Accumulation of iron and arsenic in thee Chandina alluvium of the lower delta plain, Southeastern Bangladesh. Environ Geochem Health. https://doi.org/10.1007/s10653-008.

Publisher's Note Springer Nature remains neutral with regard to jurisdictional claims in published maps and institutional affiliations. 